\title{
Effect of seed priming and foliar application with micronutrients on quality of forage corn (Zea mays)
}

\author{
Rozhin Sharifi, Khosro Mohammadi*, Asad Rokhzadi \\ Agronomy Department, Sanandaj Branch, Islamic Azad University, Sanandaj, Iran \\ *Corresponding author, E-mail: khosromohammadi60@yahoo.com
}

\begin{abstract}
The effect of seed priming and foliar application with micronutrients zinc and iron (in both nano- and chemical formulations) on quality of forage corn (Zea mays L.) under field and greenhouse conditions was studied during two years. Seed priming and foliar spraying were performed with six treatments: nano-iron chelate, nano-zinc, chemical iron chelate, chemical zinc fertilizer, distilled water and control. Results indicated that both forms of iron fertilizer increased leaf chlorophyll concentration, compared to other spraying treatments and the control. The highest plant height, total dry biomass, crude protein, soluble carbohydrates and phosphorus uptake were obtained in the nano-iron spraying treatment. Significant improvement in leaf chlorophyll concentration, plant height, total dry matter, crude protein and soluble carbohydrates occurred as a result of spraying with both forms of zinc, but more evident for the nano-zinc treatment, compared with the control. Further studies are needed to elucidate the optimum timing of application, mode of action and critical range of nano zinc and iron concentrations. Aplication of nano-forms of fertilizers, compared to chemical forms of fertilizers, increased the phosphorus concentration, biomass, and crude protein and soluble carbohydrate concentration.
\end{abstract}

Key words: forage corn, iron, nano-fertilizers, seed priming, Zea mays, zinc.

Abbreviations: TDB, total dry biomass.

\section{Introduction}

Sufficient food production with suitable quality for the growing world population has made it necessary to revise common crop production systems. Application of fertilizers increase crop productivity, but excessive application of chemical fertilizers in common agricultural production systems has caused environmental problems in many countries, including Iran. Crop plants typically use less than half of the chemical fertilizers applied (Loomis, Connor 1992). The remaining minerals may leach to deeper layers, disturb soil mineral balance and decrease soil fertility, and cause irreparable damage to the soil structure, mineral cycles, soil microbial flora, and plants (Solanki et al. 2015). Therefore, there is an urgent need to develop smart materials that can systematically release chemicals to specific targeted sites in plants which would be beneficial in controlling nutrition deficiency in agriculture.

Nano-fertilizers havehigh surface area,sorption capacity, and controlled-release kinetics to targeted sites, and have been considered as smart delivery system. In agricultural systems, nanotechnology can increase crop growth and save energy, to promote better and more economic food production (Rameshaiah et al. 2015). Spraying nanofertilizers requires lesser amounts and has lower cost that chemical fertilizers. The entry of nanoparticles through cell walls depends on the pore diameter of the cell wall (5 to 20 nm; Fleischer et al. 1999). Hence, nanoparticles aggregates with diameter less than the pore size of plant cell wall can easily enter through the cell wall and reach up to the plasma membrane (Moore 2006; Navarro et al. 2008).

Microelements play a vital role in growth and quality of crops. The uptake of micronutrients is reduced in calcareous soils, and in conditions of low organic matter content and high application of phosphorus fertilizers (Safyan et al. 2012). Among micronutrients, iron and zinc are important nutrients that have a vital role in corn production (Potarzycki, Grzebisz 2009). Babaeian et al. (2011) estimated that zinc and iron deficiencies are common in 30 and $50 \%$ of soils, respectively, worldwide. Zinc is the second most abundant transition metal and it is important for membrane integrity and phytochrome activity (Parsad et al.2012). Spraying of iron nano-fertilizer has been shown to increase soybean grain yield (Sheykhbaglou et al. 2010). Foliar application of zinc was observed to increase dry matter of corn, wheat and sunflower while zinc deficiency reduced total dry matter of corn from $26.6 \%$ to $74 \%$ depending on cultivar (Trehan, Sharma 2000).

In addition to spraying, micronutrients may be used as a pre-sowing treatment. Priming is the simplest method to hydrate seeds in order to improve germination and seedling emergence in many crop species. Osmopriming is a pre-sowing treatment that consists of seed incubation in an osmoticum solution, such as with microelements. 
Main root length, dry weight and leaf area of groundnut were significantly affected by seed treatment with calcium and zinc (Geeta et al. 1996). Seed priming with zinc can improve crop emergence, seedling establishment and seed metabolism (Farooq et al. 2012).

Maize or corn (Zea mays L.) is globally the most important cereal in terms of production and maize stover. It is widely used as fodder in many regions of the world (Erenstein et al. 2013). No studies have been conducted to investigate effect of spraying and priming with nano- and chemical forms of micronutrients in forage. Considering the high requirements of forage corn to fertilization inputs in addition to the environmental effects of chemical fertilizers, it seems that application of fertilizers with nanotechnology may be a good alternative in forage maize production. Therefore, this study was aimed to assess the forage corn response to the application of nano and common chemical forms of iron and zinc fertilizers.

\section{Materials and methods}

\section{Site description}

The field and greenhouse experiments were conducted during 2015 and 2016 in the research field and greenhouse of Islamic Azad University of Sanandaj ( $35^{\circ} 11^{\prime} \mathrm{N}$; $46^{\circ} 59^{\prime} \mathrm{E}$, $1400 \mathrm{~m}$ above sea level) located in Kurdistan provinces of Iran. Soil (depth of 0 to $30 \mathrm{~cm}$ ) and irrigation water samples were taken in order to determine the physical and chemical properties. The main soil physicochemical properties were: clay-loam texture ( $29 \%$ sand, $41 \%$ clay and $30 \%$ silt),pH 7.21 (1:2.5 in water), $1.19 \%$ organic matter, $0.20 \%$ total nitrogen, $8.54 \mathrm{mg} \mathrm{kg}^{-1}$ Olsen phosphorus, $271 \mathrm{mg} \mathrm{kg}^{-1}$ extractable potassium, $0.912 \mathrm{mg} \mathrm{kg}^{-1}$ zinc and $62.3 \mathrm{mg} \mathrm{kg}^{-1}$ iron. The irrigationwater characteristics were: electrical conductivity $1.18 \mathrm{dS} \mathrm{m}^{-1}, \mathrm{pH} 7.3$ and sodium adsorption ratio 4.18. The soil and water characteristics were determined according to Tandon (1995).

\section{Experimental design and preparation of treatments}

The field experiment was arranged in a split plot based on a randomized complete block design with three replications. The main plots consisted of six foliar spraying treatments with micronutrients: nano-iron chelate, nano-zinc, chemical iron chelate, chemical zinc fertilizer at the rates of $2 \mathrm{~g} \mathrm{~L}^{-1}$, distilled water spraying (control 1) and control 2 (without fertilizers). Subplots were used for corn seed priming treatments as above. Distilled water was used as one control to test if effects of fertilizer treatments were due to the solvent water that used in formulation of fertilizer treatments. Fertilizers were composed of zinc sulfate $\left(\mathrm{ZnSO}_{4} \times 7 \mathrm{H}_{2} \mathrm{O}\right)$, chemical iron chelate (ferric ethylene diamine tetra acetic acid), nano-chelated iron 7\%, nanochelated zinc $12 \%$ (provided by Khazra company), $50 \%$ of fertilizer amounts were foliar sprayed at growth stage V10 (10 leaves with collars visible) and the rest sprayed at R1 (silking stage). For seed priming, corn seeds were soaked in an aerated solution of respective osmoticum with concentration $2 \mathrm{~g} \mathrm{~L}^{-1}$ of micronutrients for $24 \mathrm{~h}$ at room temperature (Nagar et al. 1998). During priming, containers were kept well aerated, as adequate oxygen is a necessity for seed respiration in osmotic seed priming. Then, seeds were sterilized using $0.05 \%$ sodium hypochlorite to eliminate microorganisms (Foti et al. 2008). Finally, the seeds were washed with distilled water for $2 \mathrm{~min}$, surface dried on absorbent paper, placed on a piece of clean germination paper, and dehydration in a drying oven at $25^{\circ} \mathrm{C}$ to obtain the original seed moisture before priming treatment. Untreated dry seeds were used as a control.

The planted corn (Zea mays) cultivar was SC704 (single cross), a late maturity hybrid. Sowing was carried out on April 27, 2015 and April 14, 2016, in the farm, and on April 15 in the greenhouse. Main plot size was $5 \times 30 \mathrm{~m}$ and spaces between main plots were $2 \mathrm{~m}$. Nitrogen fertilizers (urea 46\%) were applied twice: at sowing and V8 stages.

For measurement of some traits, a repeated experiment was carried out in a greenhouse under the following conditions: $25 / 20{ }^{\circ} \mathrm{C}$ day/night temperature and $65 \%$ relative humidity. Under greenhouse conditions, a split plot experiment based on a randomized complete block design with three replications was used (same as in the farm conditions). Air-dried soil collected from the field was placed in 30-cm-tall plastic containers with $18 \mathrm{~cm}$ diameter. After $24 \mathrm{~h}$ priming treatments, seeds were washed with distilled water, and 25 seeds were sown in each container.

\section{Measurements in greenhouse}

Emergence percentage was measured by counting all individual seedlings at $24 \mathrm{~h}$ intervals beginning from 7 days after planting and continued until no further emergence occurred [the emerged seedling number divided by total planted (25) and multiplied by 100]. At the emergence stage (VE) only three plants were retained in each pot and the other plants were removed. At silking stage (R1) three plants for each treatment were harvested and plant roots were washed with water, then root weight was measured.

\section{Measurements in field}

In the field experiment, when plants were at the R1 stage, leaf chlorophyll concentration was measured using a portable chlorophyll meter (Minolta SPAD-502). Five measurements per plant (five plants in each sub plot) were obtained from the medium part of the completely expanded leaf, at 1 to $2 \mathrm{~cm}$ from the leaf edge.

For measurement of dry matter, plants were cut at ground level in a sampling area per plot of $2 \times 3 \mathrm{~m}$ at silking stage. Plant samples were oven-dried at $60^{\circ} \mathrm{C}$ for 8 days to achieve a constant dry mass. Plant height was taken at the silking stage by measuring height of five plants from the four inner rows of each subplot. Phosphorus and nitrogen concentrations in corn forage were determined using the 
methods described in Saneoka et al. (2004); phosphorus concentration was determined using an inductively coupled argon atomic emission spectrometer (ICAP-575, Nippon Jarrel Ash, Kyoto, Japan) in a sulfuric acid and nitric acid mixture, and nitrogen concentration in dry tissues was determined in sulfuric acid digests using the semimicroKjeldahl method. Crude protein concentration was calculated by multiplying total nitrogen $\times 6.25$. The soluble carbohydrate concentration was determined according to Dubois et al. (1956). The crude fiber content was determined according to Goering and Van-Soest (1970). Total crude protein, phosphorus, soluble carbohydrates and crude fiber uptake were calculated by multiplying of the dry matter yield and nutrient concentration.

\section{Statistical analysis}

A combined analysis was performed after testing for homogeneity of variances. The data collected in this study were subjected to analysis of variance (ANOVA) using the general linear model procedure in the Statistical Analysis System and the means comparison was done using a LSD test with the SAS statistical package (SAS Institute 2002).

\section{Results}

The seed priming effect was significant for emergence percentage and root weight. Significant priming $\times$ foliar application treatment interaction was observed for root weight. Year and interaction of year with treatment had not a significant effect on any traits. Spraying of nano- $\mathrm{Zn}$ alongside with priming with both types of $\mathrm{Zn}$ formulations resulted in higher root growth than in other treatments (Table 1). Seed priming with nano- and chemical forms of $\mathrm{Zn}$ proved to be effective in increasing emergence percentage. Seed priming in water increased emergence percentage compared to that of the control (Table 2).

Leaf chlorophyll concentration was affected by spraying of fertilizers. Both forms of iron fertilizer increased leaf chlorophyll concentration, compared to other fertilizers and control. Nano-Zn treatment resulted in higher leaf chlorophyll concentration than that for the chemical form of zinc, water and control treatments (Table 2). The effects of experimental factors were significant for plant height and total dry biomass (TDB), except for priming treatments on TDB. Plant height and TDB responses were generally greater in the nano iron chelate treatment. Nanozinc spraying increased plant height by 23.6 and TDB by $14.5 \%$, respectively, compared with the control. Nanozinc spraying increased TDB by $1.5 \%$, compared with the chemical form (Table 2). In addition, seed priming with iron (both chemical and nano-) and nano-zinc resulted in a higher plant height than in chemical zinc, hydropriming and control treatments (Table 2).

It was observed that priming treatments did not show any effect on the qualitative traits of forage. Crude protein, soluble carbohydrate and phosphorus concentration, and crude fiber content were significantly affected by the spraying of fertilizers. The nano-iron treatment resulted in the highest crude protein, soluble carbohydrates and phosphorus concentration and lowest crude fiber concent as compared with the other treatments (Table 2). Zinc sources (nano- and chemical) application reduced phosphorus content, compared with the other formulations. Zinc treatment increased the soluble carbohydrate concentration compared with the water and control treatment. Nano forms increased the phosphorus, TDB, crude protein and soluble carbohydrate concentration compared to chemical forms (Table 2).

\section{Discussion}

In agreement with our results, the findings of Prasad et al. (2012) showed that nanoscale $\mathrm{ZnO}$ treatment resulted in higher germination compared to chemical $\mathrm{ZnSO}_{4}$ and a control. $\mathrm{Zn}$ is also a component of important enzymes such as proteinase, peptides and dehydrogenase, which promotes starch formation, seed maturation and production. Seed priming with zinc has very important physiological roles in seed germination and early seedling growth (Laware, Raskar 2014). Positive effects of $\mathrm{Zn}$ on germination and emergence of seeds have been reported by several investigators (Hebbern et al. 2005; Harris et al. 2008). Increased emergence percentage after application of $\mathrm{Zn}$ suggest better ability of seedlings to grow and withstand adverse environmental conditions. The review by Cakmak (2008) provides further benefits of $\mathrm{Zn}$-enriched seeds on

Table 1. Interaction effect of seed priming and foliar fertilizer spray treatment on root weight (mg per plant) in greenhouse experiments. The treatment means with the same letter are not significantly different using LSD at 5\%

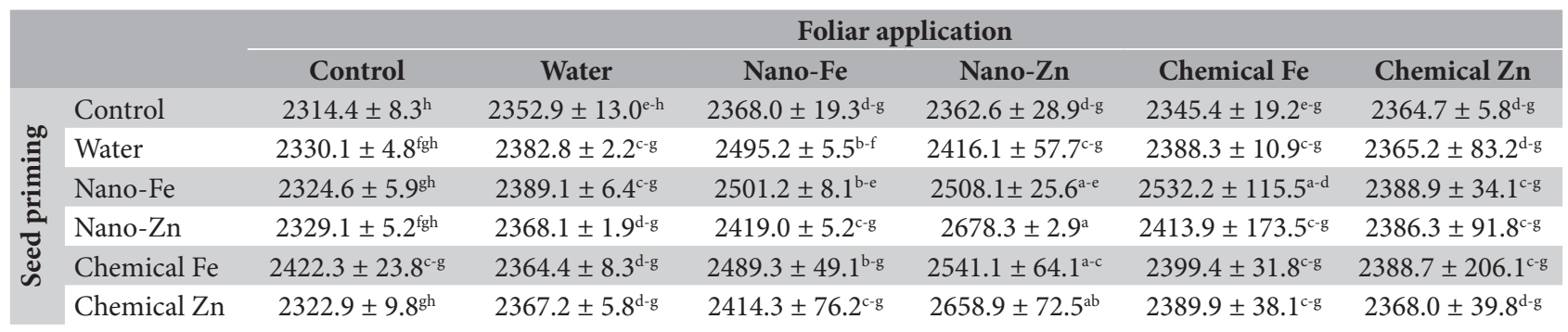


Table 2. Effect of fertilizer spraying and seed priming on agronomic traits and quality of forage corn. The treatment means with the same letter are not significantly different using LSD at 5\%

\begin{tabular}{|c|c|c|c|c|c|c|c|c|}
\hline & $\begin{array}{c}\text { Leaf } \\
\text { chlorophyll } \\
\text { (SPAD } \\
\text { units) }\end{array}$ & $\begin{array}{c}\text { Plant height } \\
(\mathrm{cm})\end{array}$ & $\begin{array}{l}\text { Total dry } \\
\text { biomass } \\
\left(\mathrm{kg} \mathrm{ha}^{-1}\right)\end{array}$ & $\begin{array}{l}\text { Crude } \\
\text { protein } \\
\left(\mathrm{kg} \mathrm{ha}^{-1}\right)\end{array}$ & $\begin{array}{c}\text { Soluble } \\
\text { carbohydrates } \\
\left(\mathrm{kg} \mathrm{ha}^{-1}\right)\end{array}$ & $\begin{array}{c}\text { Phosphorus } \\
\left(\mathrm{kg} \mathrm{ha}^{-1}\right)\end{array}$ & $\begin{array}{l}\text { Crude } \\
\text { fiber } \\
\left(\mathrm{kg} \mathrm{ha}^{-1}\right)\end{array}$ & $\begin{array}{c}\text { Emergence } \\
(\%)\end{array}$ \\
\hline \multicolumn{9}{|l|}{ Spraying } \\
\hline Control & $38.2 \pm 0.2^{\mathrm{f}}$ & $135.2 \pm 1.1^{\mathrm{e}}$ & $5451 \pm 28^{\mathrm{e}}$ & $385.432 .2^{\mathrm{f}}$ & $893 \pm 20^{\mathrm{e}}$ & $7.4 \pm 0.1^{\mathrm{e}}$ & $1390 \pm 4^{\mathrm{d}}$ & ND \\
\hline Water & $40.1 \pm 0.1^{\mathrm{e}}$ & $154.3 \pm 1.3^{d}$ & $5944 \pm 6^{d}$ & $490.7 \pm 16.3^{\mathrm{e}}$ & $939 \pm 3^{d}$ & $8.4 \pm 0.1^{c}$ & $1412 \pm 5^{c}$ & ND \\
\hline Nano-Fe & $44.4 \pm 0.1^{\mathrm{b}}$ & $184.5 \pm 1.6^{\mathrm{a}}$ & $6351 \pm 10^{\mathrm{a}}$ & $604.1 \pm 8.2^{\mathrm{a}}$ & $1045 \pm 10^{\mathrm{a}}$ & $11.7 \pm 0.3^{\mathrm{a}}$ & $1302 \pm 8^{f}$ & ND \\
\hline Nano-Zn & $43.6 \pm 0.1^{c}$ & $167.2 \pm 1.3^{c}$ & $6276 \pm 14^{\mathrm{b}}$ & $562.5 \pm 0.9^{c}$ & $992 \pm 2^{b}$ & $8.1 \pm 0.2^{\mathrm{d}}$ & $1330 \pm 20^{e}$ & ND \\
\hline Chemical Fe & $47.1 \pm 0.1^{\mathrm{a}}$ & $180.4 \pm 1.9^{\mathrm{b}}$ & $6260 \pm 27^{b}$ & $578.3 \pm 1.0^{\mathrm{b}}$ & $990 \pm 3^{\mathrm{b}}$ & $10.0 \pm 0.1^{\mathrm{b}}$ & $1486 \pm 6^{\mathrm{b}}$ & ND \\
\hline Chemical Zn & $42.8 \pm 0.1^{\mathrm{d}}$ & $154.6 \pm 0.9^{d}$ & $6176 \pm 14^{c}$ & $553.4 \pm 6.1^{\mathrm{d}}$ & $958 \pm 11^{c}$ & $7.9 \pm 0.1^{d}$ & $1514 \pm 18^{\mathrm{a}}$ & ND \\
\hline \multicolumn{9}{|l|}{ Seed priming } \\
\hline Control & $42.7 \pm 0.1^{\mathrm{a}}$ & $170.2 \pm 1.2^{\mathrm{a}}$ & $6068 \pm 32^{\mathrm{a}}$ & $523.2 \pm 16.3^{\mathrm{a}}$ & $968 \pm 14^{\mathrm{a}}$ & $8.9 \pm 0.1^{\mathrm{a}}$ & $1409 \pm 10^{a}$ & $92.1 \pm 1.1^{\mathrm{b}}$ \\
\hline Water & $42.6 \pm 0.2^{\mathrm{a}}$ & $169.3 \pm 1.2^{\mathrm{a}}$ & $6090 \pm 21^{\mathrm{a}}$ & $529.1 \pm 12.2^{\mathrm{a}}$ & $970 \pm 12^{\mathrm{a}}$ & $8.9 \pm 0.1^{\mathrm{a}}$ & $1405 \pm 11^{\mathrm{a}}$ & $97.5 \pm 1.1^{\mathrm{a}}$ \\
\hline Nano-Fe & $42.7 \pm 0.2^{\mathrm{a}}$ & $167.2 \pm 2.1^{\mathrm{a}}$ & $6081 \pm 41^{\mathrm{a}}$ & $524.3 \pm 15.3^{\mathrm{a}}$ & $968 \pm 15^{\mathrm{a}}$ & $9.0 \pm 0.2^{\mathrm{a}}$ & $1405 \pm 20^{\mathrm{a}}$ & $90.5 \pm 1.3^{\mathrm{b}}$ \\
\hline Nano-Zn & $42.7 \pm 0.2^{\mathrm{a}}$ & $162.2 \pm 1.1^{\mathrm{b}}$ & $6076 \pm 21^{\mathrm{a}}$ & $540.6 \pm 14.4^{\mathrm{a}}$ & $970 \pm 21^{a}$ & $8.9 \pm 0.1^{\mathrm{a}}$ & $1406 \pm 14^{\mathrm{a}}$ & $96.6 \pm 1.3^{\mathrm{a}}$ \\
\hline Chemical Fe & $42.8 \pm 0.3^{\mathrm{a}}$ & $154.8 \pm 2.0^{c}$ & $6071 \pm 30^{\mathrm{a}}$ & $537.2 \pm 8.6^{\mathrm{a}}$ & $970 \pm 10^{\mathrm{a}}$ & $8.9 \pm 0.1^{\mathrm{a}}$ & $1404 \pm 10^{\mathrm{a}}$ & $90.2 \pm 1.9^{b}$ \\
\hline Chemical Zn & $42.7 \pm 0.2^{\mathrm{a}}$ & $152.9 \pm 2.1^{c}$ & $6072 \pm 21^{\mathrm{a}}$ & $521.5 \pm 9.3^{\mathrm{a}}$ & $971 \pm 6^{a}$ & $8.9 \pm 0.2^{\mathrm{a}}$ & $1401 \pm 8^{\mathrm{a}}$ & $82.6 \pm 2.4^{c}$ \\
\hline
\end{tabular}

plant growth.

It has been demonstrated that iron has a great role in synthesis of chlorophyll, photosynthesis improvement and plant growth regulation (Jin et al. 2008). Amanullah et al. (2012) showed that spraying of iron sulfate increased chlorophyll concentration of corn leaf. Iron is a constituent of caproporphyrinogen oxidase, involved in the biosynthesis of $\delta$-aminolevulinic acid. Therefore, spraying with iron affects chlorophyll synthesis indirectly by affecting its precursor $\delta$-aminolevulinic acid. Iron also has a valuable role in the synthesis of chloroplastic mRNA and rRNA, which control chlorophyll synthesis (Noort, Wallace 1966; Kumawat et al. 2006). Nano-scale zinc oxide particle treatment was associated with increased stem and root growth and pod yield of peanut, compared with $\mathrm{ZnSO}_{4}$ application (Prasad et al. 2012). It was suggested that nanoscale zinc is absorbed by plants to a larger extent than its chemical form. Zinc has a significant role in cell elongation and synthesis of tryptophan (precursor of indole-3-acetic acid). Increased elongation of cells in the early stages of plant growth can lead to greater plant height and TDB (Memari Tabrizi et al. 2011).

The positive effects of foliar spray of $\mathrm{Fe}$ and $\mathrm{Zn}$ on growth as observed in the present study have also been reported in studies on rice, safflower, chickpea and soybean (Sultana et al. 2001; Khan et al. 2003; Gadallah 2000; Movahhedy-Dehnavy et al. 2009). Increase in growth as a result of application of nano-particles is possibly due to increased photosynthetic and other metabolic activity leading to an increase in various plant metabolites responsible for cell division and elongation (Hatwar et al. 2003). Iron is a component of ferrodoxin and it may improve photosynthesis; iron deficiency might be a restricting factor for vegetative growth (Hazra et al. 1987). The highest mean dry and fresh weight of stems, roots, leaves of Ocimum basilicum were obtained in the nano-iron chelated treatment (Peyvandi et al. 2011).

The observed increase of plant height in priming treatments may be due to the improved establishment of seedling, minimization of time between seed sowing and emergence and the synchronization of emergence, and promoted use of nutrient and soil moisture (Valadkhan et al. 2015).

Deficiency of iron can reduce seed protein content because of the direct positive effect of iron on protein synthesis (Cakmak et al. 2010). Nano-iron oxide produced the highest grain protein concentration in durum wheat, followed by iron sulfate and iron chelate (Ghafari, Razmju 2015). A positive close relationship has been identified between protein concentration and the concentration of iron and zinc in corn in the present study. Other researchers reported that seed protein and phosphorus concentration was increased by application of $\mathrm{FeSO}_{4}$ (Kumpawat, Manohar 1994; Shukla, Shukla 1994). Zinc fertilizers increased soluble carbohydrate concentration, probably due to involvement of zinc in photosynthesis, chlorophyll synthesis, starch formation and enzyme carbonic anhydrase, accelerating carbohydrate formation. These results are in conformity with other findings (Singh et al. 2002; Soleymani et al. 2012).

In our study, nanoparticles forms increased the nutrient uptake, and protein and carbohydrate concentration compared to that promoted by chemical forms. Nanosized formulation of mineral micronutrients may improve solubility and dispersion of insoluble nutrients in soil, reduce soil absorption and fixation, and increase 
bioavailability. These attributes of nanoparticles are due to their high surface area to volume ratio, high solubility, and specific targeting due to small size, high mobility, and low toxicity (Sasson et al. 2007). Several studies have reported the uptake of nanoparticles into plant cells via binding to carrier proteins through aquaporin, ion channels and endocytosis (Nair et al. 2010). Nanoparticles can also be transported into the plant by forming complexes with membrane transporters or root exudates (Kurepa et al. 2010). Recent studies reported that nanoparticles can enter through stomata or the base of trichomes in leaves (Eichert et al. 2008; Uzu et al. 2010), these findings are in agreement with our results showing that spraying nano-fertilizers caused significant difference in traits. However, the exact mechanism of nanoparticle uptake by plants is yet to be elucidated.

Growth and quality of corn as an important forage crop were affected by nano iron application. It seems that the use of iron nano-particles causes increase in TDB, crude protein, soluble carbohydrates and phosphorus concentration. Moreover application of nano or chemical formulations of zinc led to a significant increase in leaf chlorophyll index, plant height, TDB, crude protein and soluble carbohydrates as compared with control plants. It should be noted that the beneficial effects of nano zinc on corn plants were more pronounced than of chemical zinc. Before making recommendations regarding these materials, additional testing is required and influence of the nano-particles in forage products must be evaluated. Also, more experiments are necessary to fully understand the suitable timing, form and rate of application and also to determine the critical nutrient range for $\mathrm{Zn}$ and $\mathrm{Fe}$ in the forage to enhance the efficacy of these micronutrients.

\section{References}

Amanullah M.M., Archana J., Manoharan S., Subramanian K.S. 2012. Influence of Iron and AM inoculation on metabolically active iron, chlorophyll content and yield of hybrid maize in calcareous soil. J. Agron. 11:27-30.

Babaeian M., Tavassoli A., Ghanbari A., Esmaeilian Y., Fahimifard M.2011. Effects of foliar micronutrient application on osmotic adjustments, grain yield and yield components in sunflower (Alstar cultivar) under water stress at three stages. Afr. J. Agric. Res. 6: 1204-1208.

Cakmak I. 2008. Enrichment of cereal grains with zinc: agronomic or genetic biofortification? Plant Soil 302: 1-17.

Dubois M., Gilles K.A., Hamilton J.K., Rebers P.A., Smith F. 1956. Colorimetric method for determination of sugar and related substance. Anal. Chem. 3: 350-356.

Eichert T., Kurtz A., Steiner U., Goldbach H.E. 2008. Size exclusion limits and lateral heterogeneity of the stomatal foliar uptake pathway for aqueous solutes and water-suspended nanoparticles. Physiol. Plant. 134: 151-160.

Erenstein O., Blümmel M., Grings E. 2013. Potential for dualpurpose maize varieties to meet changing maize demands: overview. Field Crops Res. 153: 1-4.

Farooq M., Wahid A., Siddique K.H.M. 2012. Micronutrient application through seed treatments - a review. Soil Sci. Plant Nutr. 12: 125-142.

Fleischer A., O’Neill M.A., Ehwald R. 1999. The pore size of non-graminaceous plant cell walls is rapidly decreased by borate ester cross-linking of the pectic polysaccharide rhamnogalacturonan II. Plant Physiol. 121: 829-838.

Foti R., Abureni K., Tigere A., Gotosa J., Gere J. 2008. The efficacy of different seed priming osmotica on the establishment of maize (Zea mays L.) caryopses. J. Arid Environ. 72: 1127-1130

Gadallah M.A.A. 2000. Effects of indole-3-acetic acid and zinc on the growth osmotic potential and soluble carbon and nitrogen components of soybean plants growing under water deficit. J. Arid Environ. 44: 451-467.

Geeta K.N., Shankar A.G., Shiva Shankar K. 1996. Effect of molybdenum, zinc and calcium on productivity of groundnut (Arachis hypogaea Gaertu). J. Oilseeds Res. 13: 167-172.

Ghafari H., Razmjoo J. 2015. Response of durum wheat to foliar application of varied sources and rates of iron fertilizers. J. Agr. Sci. Tech. 17: 321-331.

Goering H.K., Van Soest P.J. 1970. Forage fiber analysis apparatus reagents, procedures and some applications. USDA Agricultural Research Service.

Harris D., Rashid A., Miraj G., Arif M., Yunas M. 2008. 'On-farm' seed priming with zinc in chickpea and wheat in Pakistan. Plant Soil 306: 3-10.

Hatwar G.P., Gondane S.V., Urkude S.M., Gahukar O.V. 2003. Effect of micronutrients on growth and yield of chilli. Soils Crops 13: 123-1254.

Hazra P., Maity T.K., Mandal A.R. 1987. Effect of foliar application of micronutrients on growth and yield of okra (Abelmoschus esculentus L). Prog. Hort. 19: 219-222.

Hebbern C.A., Pedas P., Schjoerring J.K., Knudsen L., Husted S. 2005. Genotypic differences in manganese efficiency: field experiments with winter barley (Hordeum vulgare L.). Plant Soil 272: 233-244.

Jin Z., Wang M., Wu L., Wu J., Shi C. 2008. Impacts of combination of foliar iron and boron application on iron biofortification and nutritional quality of rice grain. J. Plant Nutr. 31: 15991611.

Khan H.R., McDonald G.K., Rengel Z. 2003. Zn fertilization improves water use efficiency, grain yield and seed $\mathrm{Zn}$ content in chickpea. Plant Soil 249: 389-400.

Kumawat R.N., Rathore P.S., Nathawat N.S., Mahatma M. 2006. Effect of sulfur and iron on enzymatic activity and chlorophyll content of mungbean. J. Plant Nutr. 29: 1451-1467.

Kumpawat B.S., Manohar S. 1994. Effect of rhizobium inoculation, phosphorus and micronutrients on nodulation and protein content of gram. Madras Agric. J. 81: 630-631.

Kurepa J., Paunesku T., Vogt S., Arora H., Rabatic B.M., Lu J., Wanzer M.B., Woloschak G.E., Smalle J.A. 2010. Uptake and distribution of ultrasmall anatase $\mathrm{TiO}_{2}$ Alizarin red $\mathrm{S}$ nanoconjugates in Arabidopsis thaliana. Nano Lett. 10: 22962302.

Laware S.L., Raskar S. 2014. Influence of zinc oxide nanoparticles on growth, flowering and seed productivity in onion. Int. J. Curr. Microbiol. Appl. Sci. 3: 874-881.

Loomis R.S., Connor D.J. 1992. Crop Ecology: Productivity and Management in Agricultural Systems. Cambridge University Press, Cambridge.

Memari Tabrizi E., Ahmadzadeh V., Farjzadeh N. 2011. Priming effect of different times of maize seeds with nutrient elements in water stress on corn yield. Ann. Biol. Res. 2: 419-423. 
Moore M. 2006. Do nanoparticles present ecotoxicological risks for the health of the aquatic environment? Environ. Int. 32: 967-976.

Movahhedy-Dehnavy M., Modarres-Sanavy S.A.M., MokhtassiBidgoli A. 2009. Foliar application of zinc and manganese improves seed yield and quality of safflower (Carthamus tinctorius L.) grown under water deficit stress. Ind. Crops Prod. 30: 82-92.

Nagar R.P., Dadlani M., Sharma S.P. 1998. Effect of hydroperiming on field emergence and crop growth of maize genotypes. Seed Sci. Technol. 26: 1-5.

Nair R., Varghese S.H., Nair B.G., Maekawa T., Yoshida Y., Kumar D.S. 2010. Nanoparticulate material delivery to plants. Plant Sci. 179: 154-163.

Navarro E., Baun A., Behra R., Hartmann N.B., Filser J., Miao A.J., Quigg A., Santschi P.H., Sigg L. 2008. Environmental behavior and ecotoxicity of engineered nanoparticles to algae, plants, and fungi. Ecotoxicology 17: 372-386.

Noort D.V., Wallace A. 1966. Role of iron in chlorophyll synthesis. In Wallace A. (ed) Current Topics in Plant Nutrition. University of California, Los Angeles, pp. 27-28

Peyvendi M., Parande H., Mirza M. 2011. Comparison of the effects of nano-iron chelated with iron chelate on growth parameters and antioxidant enzyme activity of Ocimum basilicum. New Cell Mol. Biotech. Mag. 1: 89-98.

Potarzycki J., Grzebisz W. 2009. Effect of zinc foliar application on grain yield of maize and its yielding components. Plant Soil Environ. 55: 519-527.

Prasad T.N.V., Sudhakar K.V.P., Sreenivasulu Y., Latha P., Munaswamy V., Raja Reddy K., Sreeprasad T.S., Sajanlal P.R., Pradeep T. 2012. Effect of nanoscale zinc oxide particles on the germination, growth and yield of peanut. J. Plant Nutr. 35 : 905-927.

Rameshaiah G.N., Pallavi J., Shabnam S. 2015. Nano fertilizers and nano sensors - an attempt for developing smart agriculture. Int. J. Eng. Res. Gener. Sci. 3: 314-320.

Safyan N., Naderidarbaghshahi M.R., Bahari B. 2012. The effect of microelements spraying on growth, qualitative and quantitative grain corn in Iran. Int. Res. J. Appl. Basic Sci. 3: 2780-2784.

Saneoka H., Moghaieb R.E.A., Premachandra G.S., Fujita K. 2004.
Nitrogen nutrition and water stress effects on cell membrane stability and leaf water relations in Agrostis palustris Huds. Environ. Exp. Bot. 52: 131-138.

Sasson Y., Levy-Ruso G., Toledano O., Ishaaya I. 2007. Nanosuspensions: emerging novel agrochemical formulations. In Ishaaya I., Horowitz A.R., Nauen R. (eds) Insecticides Design Using Advanced Technologies. Springer, Berlin, pp. 1-39.

Sheykhbaglou R., Sedghi M., Tajbakhsh-Shishevan M., SeyedSharifi R. 2010. Effects of nano-iron oxide particles on agronomic traits of soybean. Notulae Sci. Biol. 2: 112-113.

Shukla V., Shukla I.C. 1994. Effect of Fe, Mo, Zn and P on symbiotic nitrogen fixation of chickpea. Indian J. Agric. Chem. 32: 118123.

Singh O., Kumar S. 2012. Productivity and profitability of rice as influence by high fertility levels and their residual effect on wheat. Indian J. Agron. 57: 143-147.

Solanki P., Bhargava A., Chhipa H., Jain N., Panwar J. 2015. Nanofertilizers and their smart delivery system. In Rai M. et al. (eds) Nanotechnologies in Food and Agriculture. Springer International Publishing Switzerland, pp. 80-105.

Soleymani A., Shahrajabian M.H. 2009. The effects of Fe, Mn and $\mathrm{Zn}$ foliar application on yield, ash and protein percentage of forage sorghum in climatic condition of Esfahan. Int. J. Biol. 4: $12--20$.

Sultana N., Ikeda T., Kashem M.A. 2001. Effect of foliar spray of nutrient solutions on photosynthesis, drymatter accumulation and yield in seawater-stressed rice. Environ. Exp. Bot. 46: 129140.

Tandon H.L.S. 1995. Methods of analysis of soils, plants, waters and fertilisers. Fertilisers Development and Consultation Organisation, New Delhi, India.

Trehan S.P., Sharma R.C. 2000. Phosphorus and zinc uptake efficiency of potato (Solanum tuberosum L.) in comparison to wheat (Triticum aestivum L.), maize (Zea mays L.) and sunflower (Helianthus annus L.). Int. J. Plant Prod. 30: 485-488.

Uzu G., Sobanska S., Sarret G., Munoz M., Dumat C. 2010. Foliar lead uptake by lettuce exposed to atmospheric fallouts. Environ. Sci. Technol. 44: 1036-1042.

Valadkhan M., Mohammadi K., Karimi Nezhad M.T. 2015. Effect of priming and foliar application of nanoparticles on agronomic traits of chickpea. Biol. Forum 7: 599-602. 